International

Medical Society

http://imedicalsociety.org

\title{
Quality of Life Assessment of the Wandering Emergency Service Care professionals

\begin{abstract}
Cristiane da Silva Ramos Marinho' Juliana Martins de Menezes ${ }^{2}$, Cecília Nogueira Valença ${ }^{3}$, Ilisdayne Thallita Soares da Silva ${ }^{4}$, Mayonara Fabíola Silva Araújo ${ }^{5}$, Luiz Alves Morais Filho ${ }^{6}$, Osvaldo de Góes Bay Júnior ${ }^{1}$, Quênia Camille Soares Martins ${ }^{7}$, Maria Leonor Paiva da Silva', Rafaela Carolini de Oliveira Távora ${ }^{6}$, Mayara Silva Fernandes do Rêgo', Renata Fonseca Sousa de Oliveira 8 , Fábia Cheyenne Gomes de Morais Fernandes ${ }^{1}$
\end{abstract}

\section{Abstract}

Introduction: The situations faced by the prehospital care professionals drive to a wear in the workplace, compromising these professionals' quality of life.

Objective: Evaluate the quality of life of the professionals who work in the Wandering Emergency Service Care in three northeastern cities of Brazil from physical and environmental aspects.

Methods: Quantitative, descriptive and transversal study, conducted at the Wandering Emergency Service Care in the cities of Caicó, Currais Novos and Santa Cruz, located in the Rio Grande do Norte State, northeastern Brazil. The data were collected from 55 professionals in October and November 2014.

Results: There was a majority of professionals aged between 25 and 29 years old, male, with high school education, income between 2 and 5 minimum wages, with other employment. The evaluation of quality of life was considered positive by most professionals. Regarding the Whoqol-Bref questionnaire there was a score variation of $65.45 \%$ to $78.76 \%$.
1 Nurse. Professor of Nursing, Faculty of Health Sciences of Trairi, Federal University of Rio Grande do Norte (FACISA/UFRN).*

2 Nurse. Specialization student in Urgent Emergency and ICU. Faculty of Health Sciences of Trairi, Federal University of Rio Grande do Norte (FACISA/UFRN).*

3 Nurse. PhD in Nursing. Graduate Program Coordinator in Public Health. Professor of Nursing, Faculty of Health Sciences of Trairi / Federal University of Rio Grande do Norte.*

4 Nurse. Master in Nursing. Faculty of Health Sciences of Trairi, Federal University of Rio Grande do Norte (FACISA/UFRN).*.

5 Nurse. Public Health Specialist. Faculty of Health Sciences of Trairi, Federal University of Rio Grande do Norte (FACISA/UFRN).*.

6 Nurse. PhD in Nursing. Professor of Nursing, Faculty of Health Sciences of Trairi/Federal University of Rio Grande do Norte.*

7 Nurse. PhD in Medical Sciences. Professor of Nursing, Faculty of Health Sciences of Trairi/Federal University of Rio Grande do Norte.*

8 Bachelor of Management in Health Systems and Services. Master student of the Graduate Program in Public Health, Faculty of Health Sciences of Trairi, Federal University of Rio Grande do Norte (FACISA/UFRN). ${ }^{*}$

*: Santa Cruz (RN), Brazil.

Contact information:

Cristiane da Silva Ramos Marinho.

झ cristiane_ramos@hotmail.com 
Conclusion: It is concluded that most of the professionals who were studied judge themselves as satisfied with their health and evaluate their quality of life positively.

\section{Keywords}

Quality of Life; Emergency

Care; Prehospital Care.

\section{Introduction}

The accelerated growth of morbidity and mortality from external causes has required a great importance action of the prehospital care, since this service minimizes health aggravations, acting in emergency cases, reducing sequelae, length of stay in the hospital environment and even mortality [1].

With the increasing number of accidents and violence in Brazil, the Wandering Emergency Service Care (SAMU) became undoubtedly of great importance for the assistance to the population in the prehospital environment. This service contributes to decrease the death rates or injuries arising from these injuries. The regionalization of this service has the objective to decrease the time/response to emergencies, providing a better assistance for the population, ensuring the universality, fairness and completeness before the attendance to the emergency [2-4].

On the other hand, the situations faced by the Prehospital Service Care professionals, which in most cases come with suffering, pain, distress and even experience with the death process, disturb and affect these individuals, resulting in the increased stress, which impacts negatively on job performance and personal life, compromising the quality of life of these professionals [5].

The wear caused by stress in the professionals of this service is evidenced mainly by the characteristics of the calls, which are emergency basis. However, the lack of knowledge of the environment, where the professional faces the unexpected, also causes an accumulation of tensions during the work journey, which compromises their own health [6].
The SAMU professionals are exposed to three types of stress: the professional, which is related to the job responsibility and the role of how it is seen and required by society; the situational, resulting from sleep deprivation, overwork, fatigue and the various situations of situations in emergencies and, finally, the personal stress, which is determined by personal characteristics such as personality, family problems, vulnerabilities, etc. [7].

These professionals are subject to suffer with wear in the workplace, increasing the chance of a bad and risk assistance, as well as weakening the whole dynamic of their work, since is required of the professional a postural balance in the various situations faced in the workplace.

Thus, due to the importance of the service provided by SAMU to the population and the roles performed by the professionals in the conduct of their functions, it is necessary to develop studies to investigate their quality of life, since it interferes directly in the patient care [8].

It is noteworthy that the factors of quality of life are closely linked to each individual routine, represented by the relationship between people and the well-being. It is noticeable that the personal and work environment contribute to the people to experience feelings and desires that lead to a good or bad satisfaction in their life. [7]

The quality of life involves not only questions related to the individual himself, but the whole context which he is inserted, like the social, physical, economic, cultural and political factors, which ends up reflecting the development of the work itself [9]. 
The workplace includes compensation issues, security conditions to minimize injuries resulting from occupational hazards, professional growth prospects, interaction between co-workers and the respect to the individuality of each individual and other features. [10]

It can be stated that the quality of life in the workplace is important, either to improve the personal life, to improve the social life or to a greater satisfaction and employee motivation with the institution, and, consequently, improved productivity [11].

Due to the existence of few publications involving the theme, the increase in external causes and the relevance of SAMU work for society, this study was developed to evaluate the quality of life of professionals working in the Wandering Emergency Service Care in the country places of Rio Grande do Norte, northeastern Brazil, from the physical and environment aspects.

\section{Methods}

The study is characterized as a quantitative, descriptive and transversal research conducted with the SAMU in the cities of Caicó, Currais Novos and Santa Cruz, located in the state of Rio Grande do Norte, Northeastern Brazil.

Professionals that are connected directly in patient care were included: drivers, nursing technicians, nurses and interventional doctors who were not on vacation, leave or removed for any reason during the data collection period.

This occurred in the period from October to November 2014, in three work shifts, covering 55 SAMU professionals. 06 of them were doctors, 08 nurses, 18 nursing technicians and 23 drivers. It is important to say that two professionals worked for SAMU in two of the cities researched.

The data were collected through a questionnaire divided into two parts. The first involved issues related to socioeconomic, demographic and labor aspects of the participants, such as age, education, income and length of service. The second was focused in measure the quality of life of individuals through the World Health Organization Quality of Life-Bref (WHOQOL-BREF), translated and validated for Portuguese. This questionnaire consists of 26 questions related to four aspects (physical, psychological, social relationships and environment).

Through the WHOQOL-BREF data, domains and total score were calculated. The mean scores were calculated on Raw Scores, being determined on a scale of 04 to 20 . On this scale, the higher the value, the higher the quality of life in the domain. Subsequently, the scores were transformed into Scores Processed and converted into a range of 0 to 100 , where values up to 25 mean higher negative domains impact in the of quality of life; 25 to 50 , average negative domains impact; 50 to 75 , little negative domains impact; 75 to 100 , no negative domains impact [12].

The data were analyzed and categorized using descriptive statistics and the scores calculation, using the Statistical Packages for The Social Sciences (SPSS) version 20.0.

For the study, there was the commitment to honor the ethical and legal principles that rule scientific research in humans, found in Resolution $n^{\circ}$. $466 / 12$ of the National Health Council, receiving the approval by the regulation of $n^{\circ} .764,013$ and CAAE 34521714.8.0000.5568.

The data collection occurred by signing the Free Consent and Informed Term (TCLE) with all participants who were informed about the research goals and voluntariness, as well as clarification to anonymity. In addition, the TCLE addressed explicitly the benefits, risks and consequences that the research would bring to these people.

\section{Results}

The results showed that there was a predominance of professionals aged between 25 and 29 years old 
(34.5\%), as shown in Table 1. The age range was between 25 and 57 years old and the standard deviation was \pm 7.59 years old.

Table 1 also shows that most of the answerers (52.7\%) completed high school and reported income of 02 to 05 minimum wages. $61.8 \%$ claim to have at least one child. Of the total surveyed, $60.0 \%$ had other employment.

The survey showed that there was a prevalence of males, $65.5 \%$ of the professionals surveyed, according to Table 2. However, if we evaluate only the category of nursing professionals, the data show reversed results, revealing a prevalence of $69.2 \%$ female, data not shown in the table.

Table 1. Distribution of variables regarding the SAMU professionals from the cities of Caico, Currais Novos and Santa Cruz, Rio Grande do Norte, Northeastern Brazil, in 2014.

\begin{tabular}{|l|c|c|}
\hline \multicolumn{1}{|c|}{ Variables } & N & $\%$ \\
\hline Age Group & 19 & 34.5 \\
\hline $25-29$ years old & 17 & 30.9 \\
\hline $30-34$ years old & 6 & 10.9 \\
\hline $35-39$ years old & 7 & 12.7 \\
\hline $40-45$ years old & 6 & 10.9 \\
\hline$>45$ years old & & \\
\hline Education & 2 & 3.6 \\
\hline High school Incomplete & 29 & 52.7 \\
\hline High school Complete & 6 & 10.9 \\
\hline Graduation Incomplete & 18 & 32.7 \\
\hline Graduation Complete & & \\
\hline Monthly Income* & 15 & 27.3 \\
\hline 1 to 2 & 29 & 52.7 \\
\hline More than 2 to 5 & 5 & 7.3 \\
\hline More than 5 to 10 & 7 & 12.7 \\
\hline More than 10 & & \\
\hline Children & 21 & 38.2 \\
\hline No & 34 & 61.8 \\
\hline Yes & & \\
\hline Other Employment & 33 & 60.0 \\
\hline Yes & 22 & 40.0 \\
\hline No & $*$ In minimum wages \\
\hline & & \\
\hline
\end{tabular}

Table 2. Gender distribution and the functions performed by the SAMU professionals from the cities of Caico, Currais Novos and Santa Cruz, Rio Grande do Norte, Northeastern Brazil, in 2014

\begin{tabular}{|c|c|c|c|c|c|c|c|c|c|c|}
\hline \multirow{3}{*}{ Gender } & \multicolumn{8}{|c|}{ Function performed in SAMU } & \multirow{2}{*}{\multicolumn{2}{|c|}{ Total }} \\
\hline & \multicolumn{2}{|c|}{ Driver } & \multicolumn{2}{|c|}{ Nurse } & \multicolumn{2}{|c|}{$\begin{array}{l}\text { Nursing } \\
\text { Technician }\end{array}$} & \multicolumn{2}{|c|}{ Doctor } & & \\
\hline & N & $\%$ & $\mathrm{~N}$ & $\%$ & $N$ & $\%$ & $\mathrm{~N}$ & $\%$ & N & $\%$ \\
\hline Female & 0 & 0.0 & 8 & 14.5 & 10 & 18.2 & 1 & 1.8 & 19 & 34.5 \\
\hline Male & 23 & 41.8 & 0 & 0.0 & 8 & 14.5 & 5 & 9.1 & 36 & 65.5 \\
\hline Total & 23 & 41.8 & 8 & 14.5 & 18 & 32.7 & 6 & 10.9 & 55 & 100 \\
\hline
\end{tabular}

Regarding the assessment of quality of life by professional category, the results showed that in all categories, most professionals evaluated their quality of life as good in $74.5 \%$ of the evaluations, as shown in Table 3.

Table 3. Evaluation distribution of the quality of life for categorized SAMU professionals from the cities of Caico, Currais Novos and Santa Cruz, Rio Grande do Norte, Northeastern Brazil, in 2014.

\begin{tabular}{|c|c|c|c|c|c|c|c|c|c|c|}
\hline \multirow{3}{*}{$\begin{array}{l}\text { Quality } \\
\text { of Life }\end{array}$} & \multicolumn{8}{|c|}{ Function performed in SAMU } & & \\
\hline & \multicolumn{2}{|c|}{ Driver } & \multicolumn{2}{|c|}{ Nurse } & \multicolumn{2}{|c|}{$\begin{array}{c}\text { Nursing } \\
\text { Technician }\end{array}$} & \multicolumn{2}{|c|}{ Doctor } & \multicolumn{2}{|c|}{ Total } \\
\hline & $\mathrm{N}$ & $\%$ & N & $\%$ & $\mathrm{~N}$ & $\%$ & $\mathrm{~N}$ & $\%$ & $\mathrm{~N}$ & $\%$ \\
\hline Bad & 0 & 0.0 & 0 & 0.0 & 0 & 0.0 & 1 & 1.8 & 1 & 1.8 \\
\hline Regular & 1 & 1.8 & 0 & 0.0 & 1 & 1.8 & 2 & 3.6 & 4 & 7.3 \\
\hline Good & 18 & 32.7 & 5 & 9.1 & 16 & 29.1 & 2 & & 41 & 74.5 \\
\hline $\begin{array}{l}\text { Very } \\
\text { Good }\end{array}$ & 4 & 7.3 & 3 & 5.5 & 1 & 1.8 & 1 & 1.8 & 9 & 16.4 \\
\hline Total & 22 & 41.8 & 8 & 14.5 & 18 & 32.7 & 6 & 10.9 & 55 & 100.0 \\
\hline
\end{tabular}

To analyze the quality of life of professionals in each domain, the mean scores, standard deviation, maximum and minimum values of these domains were calculated. Considering the domains from WHOQOL-BREF questionnaire, the results were average values ranging from $65.45 \%$ to $78.76 \%$ and standard deviation of \pm 14.98 and $11.87 \pm$ to the environment and physical domains, respectively, as Table 4 
Table 4. Average score, standard deviation, minimum and maximum values of domain scores of quality of life from WHOQOL-BREF of SAMU professionals from the cities of Caico, Currais Novos and Santa Cruz, Rio Grande do Norte, Northeastern Brazil, 2014.

\begin{tabular}{|l|c|c|c|}
\hline $\begin{array}{c}\text { Domains } \\
\text { WHOQOL- } \\
\text { BREF }\end{array}$ & Minimum & Maximum & Mean \pm SD \\
\hline $\begin{array}{l}\text { Physical } \\
\text { Psychological }\end{array}$ & 50.00 & 96.43 & $78.76 \pm 11.87$ \\
\hline $\begin{array}{l}\text { Social } \\
\text { relationships }\end{array}$ & 50.00 & 100.00 & $75.90 \pm 16.87$ \\
Environment & 46.88 & 93.75 & $65.45 \pm 14.58$ \\
\hline
\end{tabular}

The satisfaction with the professionals' health is assessed positively, where $74 \%$ said they were satisfied with the health itself.

Table 5. Satisfaction with health related to professional category of SAMU professionals from the cities of Caico, Currais Novos and Santa Cruz, Rio Grande do Norte, Northeastern Brazil, in 2014.

\begin{tabular}{|c|c|c|c|c|c|c|c|c|c|c|}
\hline \multirow{3}{*}{$\begin{array}{l}\text { Satisfac- } \\
\text { tion with } \\
\text { Health }\end{array}$} & \multicolumn{8}{|c|}{ Professional Category } & \multirow{2}{*}{\multicolumn{2}{|c|}{ Total }} \\
\hline & \multicolumn{2}{|c|}{ Driver } & \multicolumn{2}{|c|}{ Nurse } & \multicolumn{2}{|c|}{$\begin{array}{l}\text { Nursing } \\
\text { Technician }\end{array}$} & \multicolumn{2}{|c|}{ Doctor } & & \\
\hline & $\mathrm{N}$ & & $\mathrm{N}$ & & & & & & $\mathrm{N}$ & \\
\hline & 0 & 0.0 & 0 & 0.0 & 0 & 0.0 & 0 & 0.0 & 0 & 0.0 \\
\hline & 0 & 0.0 & 0 & 0.0 & 0 & 0.0 & 1 & 1.8 & 1 & 1.8 \\
\hline & & & 1 & & & & & & & \\
\hline Satisfied & 17 & 30.9 & 6 & 10.9 & 13 & 23.6 & 5 & 9.1 & 41 & 74.5 \\
\hline $\begin{array}{l}\text { Very } \\
\text { Satisfied }\end{array}$ & 7 & 7.3 & 1 & 1.8 & 3 & 5.5 & 0 & 0.0 & 8 & 14.5 \\
\hline otal & & 41.8 & & & 18 & 32.7 & & & & \\
\hline
\end{tabular}

\section{Discussion}

The study showed that there was a predominance of young people in the workplace. The prevalence of this range is a factor that contributes positively, since this population is in the most productive phase of their lives, with greater agility and skill, favoring the quality of care in emergency situations, meeting with other studies that shows that the low age team drives to a better care [13].

The data also showed that professionals who have only completed the high school, followed by professionals with graduation were the most prevalent. It is believed that this result occurred due to the government stimulus in increasing the schooling of the Brazilian population in recent years.

The remuneration of the professionals surveyed are in a salary range that varies from two to five minimum wages, the range is within the expected, since most of the surveyed professionals perform driver or nursing technician functions, whose income is not very high. In a research made with SAMU nursing professionals in Brasilia showed that the wage income of these was more than four times the minimum wage, making most of them to have seven to ten salaries (67.2\%) [14].

The predominance of the professionals who had children was also observed. In a study with a SAMU team in the city of Natal, northeastern Brazil, it was also observed that most professionals have children [13]. The presence of children in the life of professionals who perform so stressful jobs is something that can be seen as beneficial to their quality of life, since children often encourage the parents to have leisure activities, and provide happy moments in the lives of their parents, reducing the stress of daily life.

In this study, most of the surveyed have other employment. This buildup is worrying because of the possible triggering of excessive professional workload, which can contribute to physical wear, undermining the health of workers, affecting their quality of life [5]. It is believed that also the double work journey for some professionals may be related to the low remuneration in the area, causing them to seek other ways to supplement their income. [7]

Regarding gender, the study showed a male predominance. Similar data were found in Florianopo- 
lis, southern Brazil, in a survey conducted in the SAMU, with the entire team to assess the health and workers' quality of life, also observed a majority of males, accounting for about $51.2 \%$ of the surveyed [5]. The male predominance is something positive in this type of service, because it requires, in some cases, physical efforts to transport patients, and courage to enter in hazardous environments. And these features are present in males.

In the particular case of the nursing staff, the survey showed that prevailed females, the same can be observed in other studies of this subject [7, 13, 14]. This is something that comes from the beginnings of the occupation creation, which has in its composition the majority prevalence of females, therefore, it was something to be expected.

About the professional category, drivers represent the predominant class. It is believed that the number of drivers has been prevalent due to the need of this professional in all wandering units, which does not occur with the other professional categories, because the crew of a basic support unit consists in at least one nursing technician and a driver, and the crew of advanced support unit consists in at least a nurse, an interventional doctor and a driver.

Analyzing the professional's answers regarding quality of life, it was observed that most of them consider it as good, showing a good level of satisfaction with it. The same happened in a study with SAMU professionals in Florianopolis, southern Brazil, where most answered as good or very good [5]. These findings are important because identifying a good quality of life for professionals who perform daily functions involving physical stress situations, risk of death, stress, among others, is something that needs to be stimulated to preserve the quality of care being provided, as well as for maintaining the well-being of these professionals.

This domain brings issues related to leisure, safety, housing and others, that despite meaning too much to the quality of life variables are not fully controlled by the professionals, affecting their quality of life.

In the physical domain, questions are made to assess how is the physical state in relation to the development of the daily activities in general. Questions about the ability to perform activities during the routine, evaluation of sleep, ability to move around, if any physical pain brings limitations, and other questions. In the survey, these professionals develop their activities without any difficulties.

It is believed that the good quality of life that the surveyed professionals think they have, is due to the recent implementation of the SAMU in the surveyed cities, the small number of occurrences in relation to the SAMU in large cities, as well as the short time of professional activity in this service. Knowing this, the present study comes to confirm that even the Prehospital Service Care being so exhausting, the professionals consider they have a satisfactory quality of life. These findings bring good expectations both for professionals and for the service itself.

This study has the limitations of the small number of professionals surveyed, as well as geographical space studied restricted to three cities with brand new implemented services, some with approximately one year of operation, which can lead to bias in the results.

\section{Conclusion}

The suerveyed profile is composed mainly of individuals aged between 25 and 29 years old, male, who finished high school, with income between 02 to 05 minimum wages, with children and with other employment. The existence of other employments in some cases of the staff members deserves a better attention, because excessive working hours may cause wear.

Most of the studied professional say they are satisfied with their health and evaluate their quality of life positively, what can be proven by the application 
of the WHOQOL-BREF instrument, whose average scores for the domains represented a small negative impact in the quality of life.

Thus, to identify how is the quality of life of the professionals who are subject to wear in the workplace has of great value, because it enables reflections and activities development, together, with managers to turn our attention to the quality of life, to maintain the health of these professionals, thereby ensuring the excellence of the service for users who need the care.

It is essential to emphasize the importance of this issue with these professionals, encouraging new researches, involving the same scenario in a perspective to deepen more on the subject and know whether the results will change over the years.

\section{References}

1. Brasil. Ministério da Saúde. Secretaria-Executiva. Subsecretaria de Planejamento e Orçamento. Plano Nacional de Saúde - PNS: 2012-2015. Brasília: Ministério da Saúde, Brasília, 2011.

2. Maia ÊC, Miranda MDC, Caetano JÁ, Carvalho ZMF, Santos MCL, Caldini LNC. Avaliação do nível de estresse de equipe de enfermagem de serviço de atendimento móvel de urgência. $R$. pesq.: cuid. fundam. 2012; 4:3060-68.

3. França CR, Barbosa RM. Manual Técnico Operacional da Central SAMU 192 Sergipe. Livro do Aprendiz 4 / Fundação Estadual de Saúde - Secretaria de Estado da Saúde de Sergipe. - Aracaju: FUNESA, 2011. p. 96.

4. Brasil. Ministério da Saúde. Portaria n. ${ }^{\circ} 1010$ de 21 de maio de 2012. Redefine as diretrizes para a implantação do Serviço de Atendimento Móvel de Urgência (SAMU 192) e sua Central de Regulação das Urgências, componente da Rede de Atenção às Urgências. Brasília, 2012.

5. Stumm EMF, Ribeiro G, Kirchner RM, Loro MM, Schmidt CL, Rosanelli P. Avaliação da saúde e qualidade de vida: profissionais de um SAMU. Cogitare Enfermagem. 2009; 14: 620-607.

6. Caldeiro ARL, Miasso Al, Corradi-Webster CM. Estresse e estratégias de enfrentamento em uma equipe de enfermagem de Pronto Atendimento. Rev. Eletr. Enf. 2008; 10:51-62.

7. Niquerito AV. Avaliação da sintomatologia do estresse, níveis de resiliência e qualidade de vida dos trabalhadores da área da enfermagem da rede pública de saúde do município de Bauru/ SP [monografia] [Internet]. Universidade do Sagrado CoraçãoGEPPH-USC; 2009
8. Lourenção LG, Moscardini AC, Soler ZASG. Saúde e qualidade de vida de médicos residentes. Rev Assoc Med Bras, São José do Rio Preto. 2010; 1: 81-91.

9. Chiavenato I. Recursos humanos: o capital humano das organizações. $8^{a}$ ed. São Paulo: Atlas; 2008.

10. Silva CLV. Qualidade de vida no trabalho [monografia]. Faculdade de Ciências Humanas Esuda; 2014.

11. Carvalho JF, Martins ÉPT, Lúcio L, Papandréa PJ. Qualidade de vida no trabalho e fatores motivacionais dos colaboradores nas organizações. Educação em Foco. 2013; 7: 21-31.

12. Martins MB, Araújo TPF, Ferreira LB, Peixoto HM. Qualidade de vida dos enfermeiros da atenção primária à saúde de Brasília DF. Gestão e Saúde. 2013; 4:293-02.

13. Campos RM, Farias GM, Ramos CS. Satisfação profissional da equipe de enfermagem do SAMU/Natal. Rev. Eletr. Enf. 2009; 11:647-57.

14. Muniz EFP. Satisfação com o trabalho e a qualidade de vida entre Enfermeiros do Serviço de Atendimento Móvel de Urgência no Distrito Federal [monografia]. Faculdade de Ciências.
Publish in International Archives of Medicine

International Archives of Medicine is an open access journal publishing articles encompassing all aspects of medical science and clinical practice. IAM is considered a megajournal with independent sections on all areas of medicine. IAM is a really international journal with authors and board members from all around the world. The journal is widely indexed and classified Q2 in category Medicine. 